\title{
PARADIGMA LIBERAL ARTS DALAM PENDIDIKAN DI ERA DISRUPSI STUDI KASUS DI ZAYTUNA COLLEGE
}

\author{
Kurniawan Dwi Saputra \\ Prodi PAI, Universitas Islam Indonesia \\ E-Mail: Kurniawan.dwi.saputra@uii.ac.id
}

\begin{abstract}
Amidst the noisy discourse of disruption era, the orientation of education in Indonesia is in a crossed way. On the one hand, by the presidential regulation number 87 on 2017, the government wants indonesian education to foster its character education. On the other hand, the more pragmatic approach to prepare skill-based system of education as the answer to industrial demands is obvious in the more recent government discourse. Based on this background, this qualitative research tries to present liberal arts education paradigm as an alternative way to today's form of education. By studying relevant literature resources, and by evaluating its practice in Zaytuna College as the case, this research argues that liberal arts education is in line with core principles in Islamic education which views human as holistic creatures with many potentials.
\end{abstract}

Keywords: Liberal arts education, disruption era, Zaytuna college, islamic education.

\begin{abstract}
Abstrak: Ditengah hingar bingar perbincangan tentang era disrupsi, orientasi pendidikan di Indonesia berada pada persimpangan jalan. Di satu sisi, berdasarkan peraturan presiden nomor 87 tahun 2017, pemerintah menginginkan pendidikan Indonesia untuk memperkuat pendidikan karakter. Di sisi yang lain, pendekatan yang lebih pragmatis untuk mempersiapkan sistem pendidikan yang menjawab kebutuhan dunia industri sangat jelas pada diskursus-diskursus pemerintah yang lebih baru. Berdasarkan latar belakang ini, penelitian kualitatif ini, mencoba menghadirkan paradigma pendidikan liberal arts sebagai jalan alternatif bagi pola pendidikan hari ini. Melalui studi sumber pustaka yang relevan, serta dengan mengevaluasi praksisnya di Zaytuna College sebagai studi kasus, penelitian ini berargumen bahwa pendidikan liberal arts selaras dengan prinsip-prinsip pokok pendidikan Islam yang memandang manusia sebagai makhluk holistik dengan potensi yang beragam.
\end{abstract}

Kata kunci: Pendidikan Liberal Arts, Era Disrupsi, Zaytuna College, Pendidikan Islam.

\section{PENDAHULUAN}

Perhatian terhadap agama dewasa ini memperoleh urgensinya kembali. Hal ini sejalan dengan merebaknya tren dalam dinamika sosial politik yang disebut Slavoj Zizek sebagai "kulturalisasi politik" (Zizek, 2008). Kulturalisasi politik adalah kecenderungan melihat persoalan sosial yang terjadi sebagai semata clash of civilizations, alih-alih kesenjangan sosial dan ketidakadilan. Zizek tak menyebutkan agama dengan proporsi yang cukup pada bagian kritiknya terhadap "ideologi kontemporer" ini. Akan tetapi, tentu saja agama termasuk dalam konflik-konflik kebudayaan yang terjadi dewasa ini, misalnya dalam perwujudan politik identitas yang marak di banyak penjuru dunia. Gelombang terorisme baru dalam wujud gerakan ISIS juga merupakan bagian dari tren ini. Dua hal tersebut membuat kajian terhadap agama dan fenomena keberagamaan, khususnya Islam, menjadi penting. 
Selain dari pintu sosial-politik, kajian terhadap agama juga mendapatkan tempat dari gerbang epistemologis. Dewasa ini muncul paradigma baru dalam ilmu pengetahuan sosial yang melampaui rigiditas batas-batas disiplin ilmu tertentu dalam wujud pendekatan interdisipliner, multidisipliner dan transdisipliner. Dalam paradigma baru yang disebut Akhyar Yusuf (2014) sebagai paradigma konstruktivisme interpretativisme ini, sebuah fenomena tidak cukup lagi dibaca dengan batasan disiplin ilmu tertentu karena keterkaitan antar elemen sosial yang semakin erat. Contohnya, ketika Sri Mulyani menjelaskan persoalan bailout Bank Century dengan pendekatan "psikologis" alih-alih jawaban penuh dari perspektif ekonomi (Akhyar Yusuf, 2014). Hal ini juga berlaku untuk fenomena agama dan keberagamaan yang sekarang dikaji dengan kacamata multiperspektif.

Dari aspek ontologis-etis, kajian agama menjadi penting di tengah revolusi industri 4.0. Pesatnya perkembangan teknologi membawa pula kebutuhan yang sangat terhadap kerangka etik yang mengatur manusia untuk hidup secara harmonis dengan elemen kehidupan baru: artificial intelligence. Sebagai contoh, dalam menghadapi fenomena revolusi industri 4.0 ini, Jepang menggagas sebuah kerangka besar masyarakat yang memanfaatkan perkembangan teknologi dengan manusia sebagai titik pusat; Society 5.0 (Jepang, 2019).

Dalam menghadapi era disrupsi, dunia pendidikan nasional seperti berada di persimpangan jalan. Di satu sisi, pemerintah menginginkan pendidikan yang menguatkan aspek karakter. (Muthoifin, 2015) Hal itu terwujud dalam bentukPerpres(Peraturan Presiden) No. 87 tahun 2017 tentang Penguatan Pendidikan Karakter. Di sisi yang lain, kebutuhan dunia industri juga membuat pemerintah ingin mengarahkan pendidikan yang selaras dengan kebutuhan dengan dunia kerja.

Berdasarkan latar belakang tersebut, pada makalah ini penulis bermaksud mendiskusikan paradigma liberal arts sebagai alternatif kerangka pendidikan di Indonesia, khususnya bagi perguruan tinggi agama Islam. Hal itu penulis sajikan dengan membandingkan prinsip-prinsip pokok dalam pendidikan liberal arts dengan pendidikan Islam. Penulis juga memaparkan secara singkat, penerapan liberal arts di perguruan tinggi muslim Zaytuna College, Berkeley, AS.

\section{METODE PENELITIAN}

Penelitian ini adalah penelitian kualitatif. Jenis penelitiannya adalah studi pustaka. Sumber data diambil dari literatur kepustakaan seperti buku, jurnal, dan data teks elektronik yang berkaitan dengan tema kajian. Data-data tersebut dianalisis dengan triangulasi data; reduksi data, penyajian data dan penarikan kesimpulan.

\section{Landasan Teori: Liberal Arts}

Secara bahasa, liberal arts berasal dari gabungan dua kata dalam bahasa latin, yaitu liberalis yang bermakna bebas dan ars yang berarti seni atau praktik yang berdasarkan prinsip-prinsip. Tokoh yang diketahui menggunakan istilah ini pertama kali adalah Cicero, filsuf dan negarawan Romawi, dalam bahasa latin artes liberales (Zakaria, 2015). Dari etimologinya, kita dapat menyimpulkan bahwa liberal arts berkaitan dengan kebebasan individu. Dalam sejarahnya, pendidikan liberal arts memang berkaitan dengan konteks sosial-politik masyarakat Athena dengan demokrasinya yang membutuhkan warga negara dengan kualitas yang berbeda dari kebudayaankebudayaan sebelumnya.

Orientasi pendidikan suatu masyarakat selalu berkaitan dengan 
warna kebudayaan yang menaunginya. Sebelum masa Athena, pendidikan di Yunani kuno adalah ihwal membentuk arete (virtue) keksatriaan (chivalric mind) (Koji, 2012). Pada masyarakat Sparta yang terkenal dengan kemampuan fisik, pendidikan bertujuan menanamkan nilainilai militer kepada calon tentara. Hal ini bergeser pada masyarakat Athena, dimana demokrasi menjadi sistem yang mengatur kehidupan mereka. Inti dari sistem demokrasi adalah apa yang diungkap Pericles, tokoh masyarakat Athena, menjelang kematiannya, "kekuasaan tidak berada di tangan minoritas tetapi di tangan semua orang," (Zakaria, 2015).

Lantaran ihwal tersebut, pendidikan di Athena berkewajiban membina kemampuan pemerintahan (governance) bukan lagi hanya untuk segelintir elit, melainkan untuk seluruh anggota masyarakatnya. Pendidikan liberal arts bertugas mengantarkan setiap individu untuk dapat berpartisipasi dalam kehidupan publik warga negara (civic life); mengungkapkan pendapat, membuat keputusan, berargumen di hadapan pengadilan (Haidar, 2014).

Sepanjang sejarah manusia, menurut Zakaria, pendidikan memang bertujuan mempersiapkan manusia dengan latihanlatihanketerampilanyangdibutuhkanbagi perannya dalam kehidupan masyarakat (2015). Dalam masyarakat primitif, pendidikan berupa latihan keterampilan berburu, kemudian berkembang menjadi pelatihan pengetahuan dan keterampilan bertani dan berperang.

Dalam tradisi Barat, masa Athena adalah titik permulaan kebutuhan untuk mencipta "manusia bebas" dengan pendidikan akan pengetahuan murni, bukan sekadar keterampilan untuk bertahan hidup. Meski demikian, pendidikandengansemangatyangdibawa liberal arts sebenarnya telah terdapat pada peradaban-peradaban selain Yunani. Menurut Dirksen, Kontowski dan Kertz
(2017), kebudayaan India, China dan Islam memiliki sistem pendidikan yang serupa dengan pendidikan liberal.

Secara tidak langsung, Fareed Zakaria juga merujuk perkembangan liberal arts di Barat sebagai akibat dari pengaruh peradaban Islam. Zakaria merujuk Islam ketika membincang isu lokus pendidikan di Eropa pada abad pertengahan yang bergeser keluar biara-biara (2015). Ketika secara tradisional pengetahuan di Eropa berkembang di biara-biara, kebudayaan Islam telah membincang pengetahuan lebih bebas dari dominasi institusi agama di madrasah-madrasah. Konten pengetahuan yang dipelajari di madrasah-madrasah itu pun bervariasi. Dari kajian agama dan sejarah hingga musik, matematika dan astronomi. Dua hal tersebut, lokus dan konten pembelajaran adalah bukti bagi eksistensi pendidikan liberal dari tradisi Islam. Hal ini juga dinyatakan oleh Zaytuna College dalam prospektusnya bahwa pendidikan Islam, alih-alih mengajarkan penguasaan spesialisasi materi-materi yang fragmentatif dan terisolasi seperti tren pendidikan kontemporer, mengajarkan pendidikan yang holistik dan menekankan pada prinsip-prinsip universal (Zaytuna, tanpa tahun).

Perdebatan mengenai tujuan dari pendidikan juga terdapat dalam tradisi liberal. Zakaria (2015) menerangkan bahwa Plato memandang tujuan dari belajar adalah untuk mencapai kebenaran, sementara Isocrates berpendapat bahwa penguasaan liberal arts bertujuan untuk mendapatkan kehidupan yang baik. Dari perdebatan itu, Zakaria (2015) menyimpulkan bahwa pendidikan liberal mempunyai dua fungsi, filosofis sekaligus praktikal.

Pendekatan dualistik ini dalam sejarahnya kemudian mengkristal menjadi klasifikasi konten pembelajaran. Pembelajaran liberal arts dimulai dengan tiga materi pokok yang dikenal dengan 
sebutan trivium: grammar, logika, retorika. Setelah materi tersebut, barulah diajarkan empat materi berikutnya yang disebut quadrivium: aritmatika, geometri, musik dan astronomi (Zakaria, 2015).

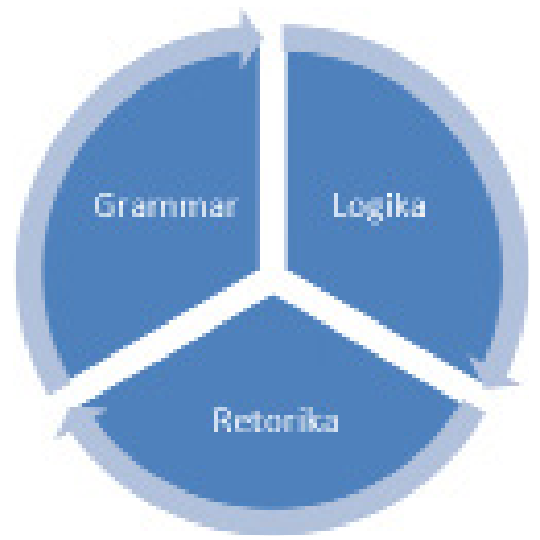

Gambar 1: Ilustrasi trivium dalam pendidikan liberal arts.

Dari preferensi dan tahapan pembelajaranyangmengutamakantrivium atas quavidrium, penulis menyimpulkan bahwa pada hakikatnya pendapat Plato lebih tepat untuk menjelaskan tujuan dari pendidikan liberal arts. Bahwa pendidikan tidak punya tujuan selain tujuan paripurna dari dalam dirinya sendiri, yakni meraih kebenaran. Hal ini selaras dengan panjelasan Hasna Haidar bahwa pembelajaran quavidrium adalah latihan untuk mempersiapkan diri pada kajian yang lebih rumit, yakni filsafat dan teologi (2014). Dengan redaksi yang berbeda, Zakaria juga menyinggung hal ini dengan menyebut bahwa pembelajaran ilmu pengetahuan alam/sains pada zaman dahulu ditujukan sebagai jalan bagi pengetahuan yang lebih abstrak seperti filsafat dan teologi (Zakaria, 2015). Dengan demikian, pendapat Zakaria yang menyimpulkan bahwa pendidikan liberal arts juga memiliki fungsi praktikal harus dipahami bahwa pembelajaran murni, elaborasi disiplin ilmu yang dipandang tidak memiliki tujuan instan dalam liberal arts, bagaimanapun juga akan tetap memiliki manfaat. Manfaat tersebut adalah pengembangan nuansanuansa kemanusiaan seperti kemampuan berpikir kritis, retorika, nalar seni dan etika yang akan selalu menjadi pokok bagi peradaban manusia. Pesan inilah yang Zakaria menyatakan ini dalam bukunya In Defense of Liberal Arts Education.

\section{Prinsip Utama Pendidikan Islam}

Terdapat perbedaan pendapat di kalangan ulama Islam mengenai kata bahasa Arab yang paling tepat untuk mengungkapkan istilah pendidikan. Sebagian berpendapat pendidikan paling tepat diungkapkan dengan altalim lantaran merupakan derivasi dari kata 'ilmun, sementara kata tarbiyah lebih luas penggunaannya dalam alQur'an (Nata, 2005). Abuddin Nata juga mengutip pendapat Raghib al-Ashfahani yang menyatakan bahwa tarbiyah berarti pengembangan dan pertumbuhan secara bertahap dan konsep tersebut sangat cocok dengan istilah pendidikan. Sementara Alattas, lebih memilih istilah ta'dib sebagai padanan paling tepat bagi kata pendidikan dengan alasan kata adab bermakna keselarasan antara tubuh, pikiran dan jiwa sehingga lebih mewakili aspek-aspek pendidikan Islam (Alattas, 1980).

Terlepas dari perdebatan tentang istilah tersebut, ketiga pendapat tersebut memandang adanya aspek transendental dari ilmu dan pendidikan manusia. Dalam ta'lim terdapat hibah ilmu yang membuat manusia lebih mulia dari binatang, dalam tarbiyah ada unsur-unsur rabbaniyah karena berasal dari kata yang sama dengan kata Rabb (Tuhan), dan dalam ta'dib memandang keharmonisan tersebut tercipta apabila menetapkan sesuatu secara adil berdasarkan hakikatnya dari Tuhan (lihat Nata 2005, hal. 5-8 dan Alattas 1980 hal. 10-11).

Aspek transendental dari pendidikan Islam tersebut dapat pula kita abstraksi dari filosofi pendidikan Al-Ghazali dan 
Ikhwan al-Shafa. Meski Muhammad Jawwad Ridha (2002) mengklasifikasikan pemikiran pendidikan al-Ghazali sebagai aliran konservatif yang berlawanan dengan aliran rasional Ikhwan alShafa, tetapi ketika membahas hakikat pendidikan kedua aliran tersebut memandang pendidikan memiliki sifat transenden. Pada pemikiran al-Ghazali, ilmu mendapatkan urgensinya karena merupakan sarana untuk mendekatkan diri kepada Allah Swt, sementara pada pemikiran Ikhwan al-Shafa ilmu berguna untuk meningkatkan harkat manusia menuju derajat malaikat agar mendapat ridha Allah Swt (Ridha, 2002).

Sifat transendensi tersebut merupakan karakter paling mendasar dalam prinsip pendidikan Islam. Karakter tersebut nampak dalam pelbagai rumusan teoritis pendidikan Islam, misalnya dalam merumuskan visi misi dan tujuan dalam pendidikan Islam. Athiyyah alAbrasyi merumuskan tujuan pokok pendidikan Islam adalah keutamaan. Keutamaan tersebut terwujud dalam bentuk perhatian yang seimbang kepada akhirat dan dunia sekaligus (Al-Abrasyi, 1970). Sementara itu M. Natsir, seperti dikutip oleh Nata (2005), menyatakan bahwa tujuan pendidikan Islam adalah tujuan kehidupan itu sendiri, yaitu sebentuk penghambaan yang pada hakikatnya tidak dibutuhkan oleh yang disembah, melainkan sebagai upaya memperbaiki kualitas yang menyembah untuk penyembahan tersebut. Maksudnya, bahwa pendidikan adalah penumbuhkembangan semua potensi manusia secara optimal agar dapat mengabdikan diri kepada Allah Swt (Muthoifin, 2015).

Dalam pemikiran Al-Abrasyi dan Natsir di atas, kita dapat menilik bahwa karakter transendensi tersebut ternyata berkaitan erat dengan sesuatu yang sangat praktis untuk tidak menyebutnya dengan istilah sekuler, yaitu kehidupan dunia. Hal ini berkaitan dengan tugas manusia di dunia ini, yaitu untuk beribadah sekaligus menjadi khalifah di muka bumi. Dua tugas tersebut bukanlah dua tugas yang berbeda tetapi dua tugas yang saling terkait satu sama lainnya. Kekhalifahan, menurut Quraish Syihab dalam Nata, adalah tugas yang mencakup dua dimensi, yaitu jasmani dan rohani (Nata, 2005). Dua aspek tersebut, dalam pemikiran Muhammad Jawwad Ridla dikembangkan menjadi empat pilar pokok yang menyokong formasi pendidikan Islam, yaitu: iman kepada Allah Swt, tanggungjawab moral individual, relasi manusia dengan benda-benda, dan relasi manusia dengan manusia yang lainnya (Ridla, 2002).

Konsekuensi dari prinsip-prinsip di atas, secara teoritis maupun praktis, pendidikan Islam harus mampu mewakili transendensi dan praktikalitas secara komprehensif dan dialektis. Pendidikan Islam klasik, menurut AlAbrasy, berorientasikan murni pada ilmu tetapi juga memperhatikan tuntutan pekerjaan (Al-Abrasy, 1970). Kemudian dalam hal hakikat manusia, pendidikan Islam memandangnya sebagai makhluk yang kompleks dan holistik, tidak dapat direduksi menjadi satu elemen saja seperti dalam behaviorisme. Menurut Ahmad Amin, pendidikan mencakup unsur fisik, akal, keinginan, perasaan dan seluruh unsur dan kemampuan jiwa manusia (Nata, 2005). Rumusan dialektis ini banyak kita temukan dalam pemikir-pemikir muslim, misalnya dalam pemikiran Kuntowijoyo ketika mengajukan teori transendensi, humanisasi dan liberasi (Kuntowijoyo, 2004). Rumusan ini juga dapat kita telusuri dalam konsep ta'dib Syed Naquib Alattas (1980) yang lebih jelasnya akan kita bahas dalam kaitannya dengan pendidikan liberal arts. 


\section{HASIL DAN PEMBAHASAN Ragam Pendekatan Studi Islam}

Secara umum, pendekatan studi Islam di perguruan tinggi Indonesia merupakan refleksi dari corak arus utama pendekatan studi Islam di dunia. Terdapat dua corak utama pendekatan studi Islam, yaitu pendekatan ala Timur Tengah dan pendekatan akademik kampus-kampus Barat.

Sebelum terjadi perubahan arah orientasi pada periode tahun 1980an, studi Islam di perguruan tinggi Indonesia mengarah kepada pendekatan Timur Tengah. Model pendekatan yang kerap disebut adalah Universitas Al-Azhar, Kairo (Zada, 2006). Pendekatan studi model ini disebut sebagai pendekatan normatif dan ideologis terhadap Islam (Mawardi, 2012). Dalam pendekatan ini, Islam dikaji dalam posisi sebagai agama kebenaran yang bersifat transenden. Sementara itu, pendekatan studi Islam di Barat memposisikan Islam sebagai tradisi keagamaan yang hidup dan historis daripada tatanan doktrin keagamaan yang final (Mawardi, 2012).

Perbedaan tersebut sepatutnya ditempatkan berdasarkan konteks genealogi masing-masing pendekatan. Studi Islam di Timur tengah berasal dari dinamika internal keagamaan Islam sendiri sehingga bersifat ideologis. Pendekatan yang normatif teologis tersebut sebenarnya terdapat pula baik dalam dinamika internal kekristenan di Barat maupun dalam corak kajian Barat terhadap Islam yang dilakukan untuk menunjukkan keunggulan agama Kristen (Abidin, 2015).

Di sisi yang lain, inisiasi studi Barat terhadap Islam tidak bisa tidak berhubungan dengan faktor teologis pasca perang Salib. Semangat ini kemudian berkembang dalam kelindan dimensi politik pemerintah kolonial untuk mempertahankan dominasi negara-negara Barat atas wilayah-wilayah jajahannya (Rusli, 2008). Fenomena C. Snouck Hurgronje menunjukkan bahwa kajian akademik, secara langsung maupun tidak, memiliki jalinan dengan dimensi politik.

Bersama perkembangan pesat pelbagai disiplin ilmu positivistik pada abad 19, motif teologis dan politik tersebut disebut telah digantikan oleh pendekatan ilmiah yang lebih objektif dengan kemunculan studi agama (Rusli, 2008). Pendekatan tersebut mengklaim telah meninggalkan penyelidikan yang berdasarkan asumsi dan penilaian subjektif serta menerapkan standar penyelidikan ilmiah berdasarkan buktibukti empiris.

Fenomena ini, di satu sisi, membuat kajian agama menghasilkan kesimpulan mengenai irasionalitas dan primitivisme umat beragama. Normativitas teologis berganti menjadi normativitas modern. Di sisi yang lain, kesimpulan-kesimpulan tersebut seringkali digunakan untuk menunjukkan superioritas agama dan budaya Barat (Rusli, 2008).

Sebagai reaksi kritis terhadap pendekatan positivistik tersebut, lahirlah fenomenologi agama yang dengan upaya penundaan penilaian (bracketting) mencoba mengeliminasi prasangkaprasangka ideologis dan etnosentris dalam melihat fenomena keberagamaan. Meski tak lepas dari kritik, pendekatan ini, hingga taraf tertentu, berhasil menampilkan citra yang lebih adil dan penghargaan lebih terhadap agamaagama selain Barat (Zada, 2006).

\section{Urgensi Pendidikan Liberal Arts dalam Era Disrupsi}

Dalam menghadapi revolusi industri 4.0, tidak bisa dipungkiri bahwa masyarakat dunia mengalami gegar budaya. Hal ini, secara sederhana, dapat disimpulkan dari penamaan era revolusi industri keempat ini dengan istilah disrupsi. Secara bahasa, dalam 
KBBI, disrupsi merupakan kata benda (noun) yang bermakna hal yang tercabut dari akarnya. Disrupsi merupakan kata serapan dari bahasa Inggris disruption dari kata kerja disrupt yang dalam kamus Cambridge bermakna to prevent something, esp. a system, process, or event, from continuing as usual or as expected (Cambridge, tanpa tahun). Dari makna literal tersebut, disrupsi kemudian digunakan untuk menunjukkan keadaan sosial yang kacau akibat munculnya teknologi dan inovasi baru. Lyentinne dan Rose dalam Klang (2006) mengatakan, "the disruption occurs when the technology, which is introduced effects the social arrangements around which we build our lives."

Akibat fenomena ini, negara-negara di dunia beramai-ramai menyiapkan roadmap strategi menghadapi akibat yang dibawa revolusi industri terbaru ini. Jerman menyiapkannya tiga tahun yang lalu, Amerika baru memulai. Di wilayah Asean, Thailand, Malaysia, Singapura dan termasuk Indonesia turut mempersiapkan (Wijaya, 2018).

Bagian dari roadmap tersebut yang berkaitandenganduniapendidikanadalah peningkatan kompetensi SDM melalui program link and match antara pendidikan dan industri (Kemenperin, tanpa tahun). Selain itu, pemerintah juga akan memberi prioritas lebih bagi pendidikan vokasi. "Oleh sebab itu, vokasional training, vokasional school masih menjadi sebuah fokus kita, konsentrasi kita untuk perbaiki kualitasnya,» sebut Jokowi dikutip Setiawan (2018).

Prioritas tersebut bersifat positif selama merupakan upaya peningkatan kualitas sistem pendidikan vokasi nasional. Akan tetapi, kebijakan tersebut ternyata membawa konsekuensi lain, yaitu pengesampingan pendidikan yang, meminjam istilah Presiden Jokowi, bersifat normatif. "Kita ingin pendidikan yang fokus pada keterampilan bekerja. Guru yang terampil (keterampilan) harus lebih banyak dari guru normatif," ujar Presiden Jokowi dikutip Nuraini (2019). Dalam tataran praktis, tendensi ini selaras dengan kebijakan pemerintah memotong kuota beasiswa LPDP untuk disiplin ilmu sosial humaniora (Atmosuwito, 2018).

Fokus yang berlebihan pada pendidikan berbasis keterampilan praktis ini patut dipertanyakan. Faktanya, berdasarkan kajian McKinsey Global Institute yang dikutip Adam (2019), pada tahun 2030 sekitar 56,7 juta pekerjaan di Indonesia akan tergantikan oleh sistem otomatis. Berbeda dengan pemerintah Indonesia, Jepang dengan Society 5.0 menyiapkan desain masyarakat yang memperhatikan aspek kemanusiaan di tengah perkembangan teknologi tersebut (Jepang, 2019).

Secara prinsipil, semangat dalam roadmap ini bertentangan dengan nilai pendidikan liberal arts. Dalam buku In Defense of a Liberal Education (2015), Zakaria mengkritik kecenderungan pendidikan yang hanya memerhatikan skill-based learning dengan menyatakan bahwa sepanjang sejarahnya, keunikan pendidikan di Amerika Serikat adalah karena tidak fokus pada pendidikan keterampilan melainkan pada liberal arts.

Pada hakikatnya, orientasi pendidikan liberal memang bertentangan dengan pendidikan praktikal. Hal ini dapat disimpulkan dalam tulisan Seneca, seorang filsuf dan ilmuwan Romawi, yang membedakan liberal arts dari pendidikan vokasi.

"You have been wishing to know my views with regard to liberal studies. My answer is this: I respect no study, and deem no study good, which results in moneymaking... they are our apprenticeship, not our real work. Hence you see why "liberal studies" are so called; it is because they are studies worthy of a free-born gentleman. But there is only one really liberal study, - that which gives a man his liberty. It 
is the study of wisdom, and that is lofty, brave, and great-souled." (Seneca)

Dalam lingkungan di AS yang juga cenderung memprioritaskan pendidikan keterampilan, Zakaria berargumen bahwa pendidikan liberal lah yang menjadi jiwa dari perkembangan teknologi. Ia menyebut bahwa Jeff Bezos, pendiri Amazon, sangat memperhatikan kemampuan menulis jajaran direksinya. Zakaria juga menyatakan bahwa Facebook bisa menjadi seperti saat ini lebih dikarenakan psikologi alih-alih teknologi. Ketika meluncurkan produk baru Apple, Steve Jobs mengatakan "it is in Apple's DNA that technology alone is not enough. It's technology married with liberal arts, married with the humanities, that yields us the result that makes our hearts sing." (Zakaria, 2015).

\section{Liberal Arts di Zaytuna College}

Zaytuna College adalah perguruan tinggi yang terletak di Hayward, Berkeley, California. Perguruan tinggi ini didirikan oleh Hamzah Yusuf pada tahun 2009 (Sinclair, 2016). Dalam prospektusnya, Zaytuna mendeskripsikan diri sebagai universitas muslim pertama di AS yang terakreditasi oleh lembaga resmi (Zaytuna, 2019). Dengan menyediakan pendidikan tinggi, Zaytuna bertujuan menyandingkan pendidikan liberal arts dalam tradisi Islam. Tujuan tersebut secara tidak langsung merupakan upaya Zaytuna untuk menjadi mediator antara tradisi Islam dengan tradisi AS secara khusus dan tradisi Barat modern secara umum (Sinclair, 2016).

Secara filosofis, Zaytuna menghubungkan konsep pendidikan liberal dengan filosofi pendidikan Syed Naquib Alattas (Zaytuna College, 2019). Menurut al-Attas, pendidikan adalah proses penanaman sesuatu kepada manusia (al-Attas, 1980). Apakah yang ditanamkan kepada manusia? Pertanyaan ini dijawab al-Attas dengan melihat kembali unsur distingtif dari manusia menurut pendapat ulama muslim, yaitu al-nuthq. Al-nuthq, menurut al-Attas adalah aspek luaran dan ekspresi dari elemen internal manusia yang lebih kompleks, yaitu al-'aql (al-Attas, 1980). Menurutnya, al-'aql tidak bisa dimaknai sebagai rasionalitas semata, karena secara etimologi ia memiliki makna binding (mengikat) dan withholding (menahan). Al'aql juga berkaitan dengan al-qalb karena merupakan organ kognisi spiritual. Oleh karena itu, pendidikan, bagi alAttas adalah penanaman sesuatu kepada fakultas-fakultas kompleks dari manusia yang terangkum dalam tiga elemen, yaitu body, mind dan soul (jasad, akal dan jiwa). Kebutuhan ketiga elemen tersebut hanya dapat terpenuhi apabila pendidikan merupakan sebuah upaya komprehensif yang terangkum dalam term ta'dib (alAttas, 1980).

Konsep ta'dib ini dipandang Zaytuna selaras dengan prinsip pendidikan liberal yang menekankan pada pemenuhan seluruh potensi manusia secara utuh. Terma ta'dib mengandung makna kesantunan, perilaku, tata krama, etiket, moralitas, kepatutan dan kemanusiaan (Zaytuna, 2019). Karena sifatnya yang komprehensif, Zaytuna menjadikan adab sebagai misi pokok pendidikannya yang holistik. Konsep holistik tersebut tercermin dalam kurikulum Zaytuna yang saling terkoneksi dan bergantung antar pelbagai disiplin ilmu yang berbeda (interdependence of disciplines). Misalnya, pembelajaran astronomi menyinggung pula permasalahan teologi, studi politik terkait erat dengan kajian etika, dll., (Zaytuna, 2019).

Pada praksisnya, Zaytuna College mengaplikasikan liberal arts melalui pengajaran trivium, yaitu grammar, logika dan retorika sebagai bagian yang terhubung dengan pengajaran materimateri keislaman seperti fiqih, hadis, 
tafsir hingga tahfidz. Selain trivium sebagai dasar, Zaytuna juga membekali muridnya dengan materi-materi yang kini identik sebagai liberal arts, misalnya etika, politik, sejarah dan ekonomi (Zaytuna, tanpa tahun). Semua itu dirancang untuk memberikan sumbangsih kepada peradaban manusia melalui "systematically thinking of the world, pondering its ultimate cause and purpose, and living ethically in the course of our individual and collective lives." (Zaytuna, tanpa tahun). Hal ini selaras dengan misi pokok dari mempelajari liberal arts, yakni meraih kebijaksanaan (pursuit of wisdom) (Seneca).

\section{PENUTUP}

Disrupsiyang terjadidipelbagai aspek kehidupan adalah tantangan sekaligus peluang bagi PTAI untuk memberikan sumbangsihnya, bukan hanya bagi umat muslim atau dunia akademik, tetapi juga bagi bangsa Indonesia dan kemanusiaan secara umum. Dalam menghadapi revolusi industri 4.0, masyarakat dunia membutuhkan lebih dari sarjana yang menguasai keterampilan how to, tetapijuga manusia yang memiliki wawasan yang luas terhadap khazanah kemanusiaan, kreatifitas, etika dan terutama kebijaksanaan. Hal-ihwal tersebut adalah outcome potensial yang akan dihasilkan dari pendidikan liberal arts.

Prinsip-prinsip liberal arts yang bertujuan mengembangkan potensi manusia secara utuh adalah juga landasan nilai dari pendidikan Islam. Dalam Surat al-Mujadalah ayat 11, Allah SWT menyandingkan ikhtiar menuntut ilmu dengan keberimananan serta kemuliaan martabat. Hal ini pula yang merupakan tujuan pendidikan liberal, yakni terpenuhinya fakultas-fakultas kemanusiaan secara utuh, because they are studies worthy of man (Seneca), bukan sekadar penguasaan keterampilan praktis.

Pada ranah praksis, Zaytuna College telah melakukan inisiasi perpaduan yang harmonis antara pendidikan liberal dengan pendidikan Islam. Unsurunsur pembelajaran liberal arts menjadi bagian integral dari pembelajaran tradisi Islam untuk menghasilkan sarjana yang memiliki komitmen moral, adaptif dengan perkembangan budaya serta memberikan sumbangsih kritis dalam membentuk peradaban manusia.

\section{DAFTAR PUSTAKA}

Abidin, Z. (2015). Islamic Studies dalam Konteks Global dan Perkembangannya di Indonesia. Akademika, Vol. 20, No. 01 Januari - Juni 2015, 69-84.

Akhyar Yusuf, L. (2014). Posmodernisme: Teori dan Metode. Jakarta: RajaGrafindo Persada.

Al-Abrasyi, Mohammad Athiyyah. (1970). Dasar-Dasar Pokok Pendidikan Islam. Diterjemahkan oleh Bustamy Abdul Ghani dan Djohar Bahry. Jakarta: Penerbit Bulan Bintang.

Al-Attas, SMN. (1980). The Concept of Education in Islam. Makkah: First World Conference on Muslim Education.

Koji, T. (2012). How Aristotle's Theory of Education Has Been Studied in Our Century. Studida Classica Volume 3, 21-67.

Klang, M. (2006). Disruptive Technology: Effect of Technology Regulation on Democracy. Goteborg: Goteborg University.

Kuntowijoyo. (2004). Islam Sebagai Ilmu: Epistemologi, Metodologi, Etika. Yogyakarta: 
Tiara Wacana.

Mawardi, I. (2012). Perbandingan Model Pendekatan Studi islam di Timur Tengah dan Barat: Formulasi Model Diskursus Pendidikan Islam Di Indonesia. Edukasia, Vol. 9, Nomor 2, Juli - Desember 2012, 63-80.

Muthoifin. Pemikiran Pendidikan Multikultural Ki Hadjar Dewantara, dalam Jurnal Intizar, Vol. 21, No. 2: 299. 2015.

Muthoifin. 2015. Sistem Pendidikan Nasional dan Pendidikan Islam: Studi Kritis Pemikiran Ki Hadjar Dewantara Perspektif Islam, dalam Jurnal Wahana Akademika, Vol. 2, No. 1: 69-72.

Nata, Abuddin. (2005). Filsafat Pendidikan Islam. Jakarta: Gaya Media Pratama.

Ridla, Muhammad Jawwad. (2002). Tiga Aliran Utama Teori Pendidikan Islam: Perspektif Sosiologis-Filosofis. Diterjemahkan oleh Mahmud Arif. Yogyakarta: Tiara Wacana.

Rusli. (2008). Pendekatan Fenomenologi dalam Studi Agama: Konsep, Kritik dan Aplikasi. Islamica, Vol. 2, No. 2, Maret 2008, 141-153.

Seneca (Tanpa Tahun). On Liberal and Vocational Studies. Diterjemahkan oleh Richard Mott Gummere.

Zada, K. (2006). Orientasi Studi Islam di Indonesia: Mengenal Pendidikan Kelas Internasional di Lingkungan PTAI. Insania Vol. 11, No. 2, Jan-Apr 2006, 258-270.

Zaytuna College Website. (2019). Diakses pada 24-25 April 2019 dari https://zaytuna. edu/.

Zakaria, F. (2015). In Defense of a Liberal Education. New York: W.W. Worton \& Company. Zizek, S. (2008). Violence. New York: Picador.

\section{Website}

Adam, Helmi. (2019). Revolusi Industri 4.0 atau Society 5.0. Diakses pada 24 April 2019 dari https://www.obsessionnews.com/revolusi-industri-4-0-atau-society-5-0/.

Atmosuwito, Dendi Raditya. (2018). Kebijakan LPDP dan Nasib Ilmu Sosial Humaniora Kita. Diakses pada 25 April 2019 dari https://tirto.id/kebijakan-lpdp-dan-nasibilmu-sosial-humaniora-kita-cCFY.

Haidar, Hasna. (2014). What Is Liberal Arts Education. Diakses pada 24 April 2019 dari https://www.topuniversities.com/blog/what-liberal-arts-education.

Making Indonesia 4.0: Strategi RI Masuki Revolusi Industri Ke-4. Siaran Press. Diakses pada 25 April 2019 dari http://www.kemenperin.go.id/artikel/18967/MakingIndonesia-4.0:-Strategi-RI-Masuki-Revolusi-Industri-Ke-4

Nuraini. (2019). Pemerintah Semakin Fokus pada Pendidikan Vokasi. Diakses pada 24 April 2019 dari https://jpp.go.id/humaniora/pendidikan/330095-pemerintah-semakinfokus-pada-pendidikan-vokasi.

Setiawan, Rizki. (2018). Presiden Perintahkan untuk Fokus ke Pendidikan Vokasi dan SMK. Diakses pada 25 April 2019 dari http://psmk.kemdikbud.go.id/konten/4031/ presiden-perintahkan-untuk-fokus-ke-pendidikan-vokasi-dan-smk.

Wijaya, L. Tri. (2018). Antara Industry 4.0 dan Transportasi 5.0. Diakses pada 24 April 2019 dari https://kumparan.com/l-tri-wijaya/antara-industri-4-0-dan-transportasi-5-0 